\title{
Mice with altered BDNF signaling as models for mood disorders and antidepressant effects
}

\author{
Jesse S. O. Lindholm and Eero Castrén* \\ Neuroscience Center, University of Helsinki, Helsinki, Finland
}

\section{Edited by:}

Benjamin Adam Samuels, Columbia University/Research Foundation for Mental Hygeine, USA

\section{Reviewed by:}

Clive R. Bramham, University of

Bergen, Norway

Alex Dranovsky, Columbia

University, USA

*Correspondence:

Eero Castrén, Neuroscience Center, University of Helsinki, P.O. Box 56,

Viikinkaari 4, Helsinki 00014, Finland e-mail:eero.castren@helsinki.fi
Brain-derived neurotrophic factor (BDNF) and its receptor tyrosine kinase TrkB support neuronal survival during development and promote connectivity and plasticity in the adult brain. Decreased BDNF signaling is associated with the pathophysiology of depression and the mechanisms underlying the actions of antidepressant drugs (AD). Several transgenic mouse models with decreases or increases in the amount of BDNF or the activity of TrkB signaling have been created. This review summarizes the studies where various mouse models with increased or decreased BDNF levels or TrkB signaling were used to evaluate the role of BDNF signaling in depression-like behavior. Although a large number of models have been employed and several studies have been published, no clear-cut connections between BDNF levels or signaling and depression-like behavior in mice have emerged. However, it is clear that BDNF plays a critical role in the mechanisms underlying the actions of $A D$.

Keywords: Bdnf deficient mice, transgenic, TrkB signaling, behavior, depression, neurotrophins, BDNF

The neurotrophin brain-derived neurotrophic factor (BDNF) supports neuronal survival during development and promotes connectivity and plasticity in the adult brain by activating its tyrosine kinase receptor TrkB (Park and Poo, 2013). Impaired BDNF signaling through TrkB is associated with the pathophysiology of mood disorders and neuronal plasticity promoted by BDNF underlies some of the actions of antidepressant drugs (AD) (Duman and Monteggia, 2006; Castrén et al., 2007). BDNF mRNA and protein levels in the rodent hippocampus (HC) correlate with depressive behaviors and with anatomical changes in the HC induced by stress (Duman et al., 1997; Duman and Monteggia, 2006). Similar findings have also been reported in the brains of depressed patients (Sheline et al., 1996; Bremner et al., 2000).

Direct injection of BDNF into the dentate gyrus (DG) or CA3 regions of the $\mathrm{HC}$, which are brain regions implicated in spatial memory and in the regulation of emotionality and mood, leads to antidepressant-like effects and to enhancement of the antidepressant-like activity of paroxetine in rodent behavioral despair models (Shirayama et al., 2002; Deltheil et al., 2008). Tyrosine kinase inhibitor K252a blocks this effect, suggesting that the antidepressant-like behavior of BDNF is dependent on TrkB activity (Shirayama et al., 2002). Similar antidepressant-like behavioral effects were observed when BDNF was injected into the midbrain region, which contains serotonergic neurons projecting to forebrain regions (Siuciak et al., 1997). Furthermore, peripheral administration of BDNF produces an antidepressantlike effect similar to the effects observed with intracranial administration (Schmidt and Duman, 2010). By contrast, direct injection of BDNF into the ventral tegmental area, a brain area that contains dopaminergic cell bodies, causes depression-like behavior, and blockade of BDNF signaling in the nucleus accumbens, a brain area involved in reward and hedonic behavior, produces antidepressant-like behavior (Eisch et al., 2003; Berton et al., 2006). Therefore, the effects of BDNF on depression-like behavior depend upon the functional role of the circuitry that is targeted.

Chronic treatment with ADs, electroconvulsive shock treatment, and physical exercise all increase BNDF mRNA and protein levels in both animals and humans (Nibuya et al., 1995; Zetterström et al., 1998; Russo-Neustadt et al., 1999; Chen et al., 2001; Coppell et al., 2003; Duman et al., 2008; Marais et al., 2009). Importantly, chronic treatment with ADs restores stressinduced changes in BDNF mRNA levels in experimental animals (Nibuya et al., 1995; Duman and Monteggia, 2006). However, there is evidence that the regulation of BDNF expression by ADs is more complex. Some studies report that BDNF mRNA levels decrease shortly after $\mathrm{AD}$ administration (Coppell et al., 2003; Kozisek et al., 2008). Furthermore, different classes of ADs activate TrkB signaling after both acute and long-term administration (Saarelainen et al., 2003; Rantamäki et al., 2007), and this TrkB mediated BDNF signaling is essential for the antidepressant-like effects of ADs in rodents (Saarelainen et al., 2003; Ibarguen-Vargas et al., 2008).

\section{BDNF AND HUMAN MOOD DISORDERS}

A comprehensive review of the role of BDNF in mood disorders is beyond the scope of this review, but some remarks are useful to provide a perspective for the rodent data reviewed below. BDNF and TrkB receptor levels in the brains and BDNF concentrations in the plasma of suicidal subjects are decreased (Dwivedi et al., 2003; Kim et al., 2007). Furthermore, AD treatment increases BDNF levels in the HC of postmortem human brains (Chen et al., 2001).

A single nucleotide polymorphism (SNP) in the human BDNF gene in which valine (Val) is substituted with methionine (Met) in codon 66 (Val66Met) reduces activity-dependent BDNF release and impairs hippocampal function (Egan et al., 2003). This SNP 
is only observed in humans and is expressed throughout the general population (Val/Met: $20-50 \%$, Met/Met 3-20\%), but is more common in Asian than in Caucasian populations (Verhagen et al., 2008). Heterozygous Met allele carriers have smaller hippocampal volumes and perform worse in hippocampal-dependent memory tasks than people with the Val/Met allele (Egan et al., 2003). No clear connections exist between this SNP and clinical depression or anxiety (Gratacos et al., 2007; Verhagen et al., 2008; Gyekis et al., 2013). However, there is evidence for a higher sensitivity to stressful life events among Met-allele carriers (Kaufman et al., 2006; Hosang et al., 2014). Unexpectedly, heterozygous met-allele carriers show a better response to antidepressant drug treatments than homozygous (Val/Val or Met/Met) carriers (Niitsu et al., 2013). By contrast, a mouse model of the Val66Met polymorphism suggests an impaired response to antidepressants in Met carrying mice (Chen et al., 2006). Potential associations between the Val66Met SNP and other mental disorders, such as substance abuse, eating disorders and schizophrenia have, however, been reported (Gratacos et al., 2007; Eisenberg et al., 2013).

BDNF is abundantly expressed in blood platelets, therefore, BDNF levels in human serum are relatively high (Karege et al., 2005). Several clinical studies demonstrate that BDNF serum levels are decreased in depressed patients and that these levels recover following successful antidepressant treatment (Karege et al., 2005; Monteleone et al., 2008; Sen et al., 2008). Unfortunately, mouse blood platelets appear to contain little or no BDNF and, consequently, BDNF levels in mouse serum are low. This species difference has greatly hampered mechanistic studies into this interesting and consistent finding of the relationship between mood disorders and serum BDNF levels.

\section{GENETIC MOUSE MODELS OF ALTERED BDNF AND TrKB}

A substantial number of genetically modified mouse models with altered BDNF expression or TrkB signaling have been produced. There are several distinct approaches that have been taken to genetically modify BDNF signaling. First, the most common method involves knock down of BDNF expression from either the whole organism or from a spatially restricted region. Second, TrkB signaling is inhibited through either TrkB knockout (KO) or other strategies that decrease TrkB activity. Third, there are gain-of-function models that enhance either BDNF expression or TrkB activity. This review will summarize the results from these BDNF and TrkB genetic models that are related to mood disorders.

\section{DECREASED BDNF LEVELS}

Ernfors et al. (1994) produced mutant mice lacking BDNF, the constitutive BDNF KO, in the early 1990s. Homozygous BDNF KO mice have severe health problems and die soon after birth (Ernfors et al., 1994). However, heterozygous BDNF KO $\left[\mathrm{BDNF}^{( \pm)}\right]$mice are vital and fertile. Their BDNF mRNA and protein levels in brain are approximately $50 \%$ of their wildtype littermates (Korte et al., 1995; MacQueen et al., 2001; Ibarguen-Vargas et al., 2009). This deficiency strongly down regulates the early postnatal signaling capacity of TrkB receptors. However, in adult mice, $\operatorname{TrkB}$ phosphorylation appears to be only slightly altered, if at all (Rantamäki et al., 2011).
Similarly, forebrain-specific conditional BDNF KO mice have normal TrkB phosphorylation levels (Rantamäki et al., 2011). During normal postnatal development, the responsiveness of TrkB to BDNF is decreased, and $\operatorname{TrkB}$ simultaneously gains the ability to be activated by BDNF-independent transactivating mechanisms (Knüsel et al., 1997; Di Lieto et al., 2012). The reason and significance of these findings are currently unknown but it is possible that BDNF-independent TrkB activation mechanisms, such as zinc or adenosine induced transactivation (Lee and Chao, 2001; Huang et al., 2008), predominate in the adult brain.

The behavioral phenotypes of BDNF knock down mice are widely studied; however, results vary from one laboratory to another (Table 1). $\mathrm{BDNF}^{( \pm)}$mice have increased appetite and are usually obese (Lyons et al., 1999; Kernie et al., 2000; Chen et al., 2006). These mice appear to have normal visual, auditory, and nociceptive senses (Liu et al., 2004; Bath et al., 2008); however, they have olfactory system impairments (Liu et al., 2004; Bath et al., 2008). When tested in a novel environment, the locomotor activity of these mice does not differ from their wildtype littermates (Lyons et al., 1999; MacQueen et al., 2001; Chourbaji et al., 2004; Chen et al., 2006; Ibarguen-Vargas et al., 2009; Marais et al., 2009; Lindholm et al., 2012; Psotta et al., 2013; however see Kernie et al., 2000). $\mathrm{BDNF}^{( \pm)}$mice also show mild impairments in learning and memory. They display impaired contextual memory but have normal cued memory (Linnarsson et al., 1997; Liu et al., 2004; Chen et al., 2006). BDNF ${ }^{( \pm)}$mice also display impaired fear extinction behavior in a fear conditioning paradigm (Psotta et al., 2013). However, these findings are not consistent throughout all studies (Chourbaji et al., 2004; Uutela et al., 2012). Importantly, there are humans with heterozygous deletions of BDNF or TrkB, and these people are obese and suffer from mental retardation (Yeo et al., 2004; Gray et al., 2006).

The anxiety- and depression-like behavioral phenotypes of these mice are even more complex. Some of the studies found that anxiety-like behaviors of $\mathrm{BDNF}^{( \pm)}$mice is indistinguishable from littermate controls (Chourbaji et al., 2004; Ibarguen-Vargas et al., 2009; Lindholm et al., 2012), whereas others found that these mice are more aggressive and display increased anxiety (Lyons et al., 1999; Chen et al., 2006; Li et al., 2010). These mice do not show depression-like behavior in models of behavior despair (such as the forced swim or tail suspension tests) (MacQueen et al., 2001; Saarelainen et al., 2003; Chourbaji et al., 2004; Duman et al., 2007; Ibarguen-Vargas et al., 2009), but they do show depression-like behavior in the learned helplessness test (MacQueen et al., 2001). Furthermore, when exposed to stress, $\mathrm{BDNF}^{( \pm)}$mice demonstrate an anxiety- and depressionlike behavioral phenotype (Duman et al., 2007; Carola and Gross, 2010). Several studies have consistently shown that $\mathrm{BDNF}^{( \pm)}$ mice are resistant to classical ADs in models of behavioral despair (Saarelainen et al., 2003; Ibarguen-Vargas et al., 2009; Lindholm et al., 2012). Thus, $\mathrm{BDNF}^{( \pm)}$mice do not show any clear baseline anxiety- or depression-like behaviors, but they are more vulnerable to stress and the effects of $\mathrm{ADs}$ are blocked in these mice.

Spatially restricted BDNF KO mouse lines have been produced by crossing mice carrying floxed BDNF (flBDNF) alleles with lines expressing Cre recombinase under a tissue-specific promoter 
Table 1 | Behavioral results of heterozygous BDNF-KO mice.

\begin{tabular}{|c|c|c|c|}
\hline Behavioral tests & Result & Background & Reference \\
\hline$B W, L A$ and $F I$ & $\begin{array}{l}\text { Increased appetite and weight, and decreased } \\
\text { locomotor activity in } \mathrm{BDNF}^{( \pm)} \text {mice, but not in } \\
\text { heterozygous NT4/5, NT3, TrkC, or TrkA } \\
\text { knockout mice }\end{array}$ & $\begin{array}{l}\text { C57Bl/6 and 129Sv mixed F2 } \\
\text { background }\end{array}$ & Kernie et al., 2000 \\
\hline $\begin{array}{l}\text { Anhedonia, EPM, FST, LH, } \\
\text { NOR, OF, PA, SP, staircase }\end{array}$ & $\begin{array}{l}\text { No differences in most of tests. Longer escape } \\
\text { latencies in } \mathrm{LH}\end{array}$ & C57BI/6 and 129Sv mixed background & MacQueen et al., 2001 \\
\hline NSF, OF, RI, TST & $\begin{array}{l}\text { No behavioral changes, effects of ADs blocked in } \\
\text { heterozygous mice }\end{array}$ & C57BI/6 and 129Sv mixed background & Ibarguen-Vargas et al., 200 \\
\hline $\begin{array}{l}\text { EZM, FC, FST, LD, novel } \\
\text { cage, OF, RR }\end{array}$ & No behavioral changes & C57BI/6 and 129Sv mixed background & Chourbaji et al., 2004 \\
\hline EPM, OF & $\begin{array}{l}\text { Increased sensitivity to pre/postnatal maternal } \\
\text { environment (high or low maternal care) }\end{array}$ & C57BI/6J and/or BALB/C & Carola and Gross, 2010 \\
\hline $\mathrm{BW}, \mathrm{Fl}, \mathrm{OF}, \mathrm{RI}$ & Increased appetite, weight and aggressiveness & $\mathrm{C} 57 \mathrm{BI} / 6$ & Lyons et al., 1999 \\
\hline $\begin{array}{l}\text { BW, EPM, FC, LA, NSF, OF, } \\
\text { RI }\end{array}$ & $\begin{array}{l}\text { Increased weight, aggressiveness, and } \\
\text { anxiety-like behavior, impaired contextual but } \\
\text { intact cue memory. No changes in locomotor } \\
\text { activity }\end{array}$ & C57BI/6J & Chen et al., 2006 \\
\hline FST & $\begin{array}{l}\text { No behavioral changes, effects of ADs blocked in } \\
\text { heterozygous mice }\end{array}$ & $129 S v \times$ BALB/c & Saarelainen et al., 2003 \\
\hline $\begin{array}{l}\text { FC, pain, vision and auditory } \\
\text { tests }\end{array}$ & $\begin{array}{l}\text { No changes in senses or baseline freezing, } \\
\text { impairment in contextual memory-, but not in } \\
\text { cue memory test }\end{array}$ & C57Bl/6 & Liu et al., 2004 \\
\hline $\mathrm{FC}, \mathrm{OF}$ & $\begin{array}{l}\text { No changes in locomotor activity, but adult } \\
\text { animals have impaired fear extinction learning }\end{array}$ & $\mathrm{C} 57 \mathrm{BI} / 6 \mathrm{~J}$ & Psotta et al., 2013 \\
\hline $\begin{array}{l}\text { Spontaneus olfactory } \\
\text { discrimination }\end{array}$ & Impairment in olfactory system & C57BI/6 & Bath et al., 2008 \\
\hline FST & $\begin{array}{l}\text { Depression-like behavior after stress or MEK } \\
\text { inhibitor }\end{array}$ & $\mathrm{C} 57 \mathrm{BI} / 6 ?$ & Duman et al., 2007 \\
\hline EPM, OF & $\begin{array}{l}\text { Increased anxiety-like behavior, no changes in } \\
\text { locomotor activity }\end{array}$ & $\mathrm{C} 57 \mathrm{Bl} / 6$ & Li et al., 2010 \\
\hline ASR, BW, FC, OF, RR, WM & No behavioral changes, increased weight & $\mathrm{C} 57 \mathrm{BI} / 6$ & Uutela et al., 2012 \\
\hline WM & Impaired learning and memory & $129 / \mathrm{J} \times \mathrm{BALB} / \mathrm{C}$ & Linnarsson et al., 1997 \\
\hline FST, OF & $\begin{array}{l}\text { No behavioral changes, effects of ADs blocked in } \\
\text { heterozygous mice }\end{array}$ & C57Bl/6J & Lindholm et al., 2012 \\
\hline
\end{tabular}

Abbreviations: ASR, Acustic startle response; BW, Body weight; EPM, elevated plus-maze; FC, fear conditioning; FI, food intake; FST, forced swimming test; EZM, elevated zero maze; LA, locomotor activity; LD, light-dark box; LH, learned helplessness; NOR, novel object recognition; NSF, novelty suppressed feeding; OF, open field; PA, passive avoidance; RI, resident-intruder test; RR, RotaRod; SP, sucrose preference; TST, tail suspension test; WM, water maze.

(Table 2). Mood-related behaviors have been investigated using Cre lines directed by the $\alpha$-calcium/calmodulin-dependent protein kinase II (CamK) promoter, which drives expression in postmitotic neurons (Rios et al., 2001). These mice showed increased food intake, weight gain, anxiety-like behavior, and hyperactivity (Rios et al., 2001). Monteggia et al. (2007) also investigated two conditional BNDF KO mice lines. One line crossed flBDNF mice with human glial fibrillary acidic protein (GFAP)-Cre mice and the other with CaMKII-Cre. In GFAP-Cre mice, Cre recombinase is broadly expressed in forebrain regions during late embryogenesis, and in CamK-Cre mice it is expressed in similar regions during postnatal development (Monteggia et al., 2007). BDNF mRNA levels in the CamK-Cre $\mathrm{x}$ flBDNF mice were significantly reduced in the $\mathrm{HC}$ and the dorsal cerebral cortex, while GFAP-Cre $\mathrm{x}$ flBDNF mice lacked BDNF mRNA in a nearly identical pattern. Male conditional KOs from both lines showed hyperactivity but normal depression-like behavior. Female mice displayed normal activity scores but had increased depression-like behavior. Furthermore, ADs failed to have any effect in either sex. Chan et al. (2006) also produced two conditional BDNF KO mice lines, crossing flBDNF mice with either Nestin or CamK-Cre, which resulted in pre- and postnatal recombination, respectively. The authors found that both BDNF KO mouse lines displayed hyperactivity and aggressive behavior. In addition, both BDNF KO mouse lines displayed depression-like behavior in the tail suspension test, but lower immobility scores in the forced swim test when compared to wildtype littermates.

Inducible mice with temporally restricted manipulations of BDNF have also been made. In these mice, a pharmacological compound, such as tamoxifen or doxycycline, is used to either activate or inactivate gene expression. Monteggia et al. (2004) used this method to produce triple transgenic (NSE-tTA $\times$ 
Table 2 | Behavioral results of transgenic BDNF mice.

\begin{tabular}{|c|c|c|c|c|}
\hline Mutant mice & Behavioral tests & Result & Background & Reference \\
\hline $\begin{array}{l}\text { Inducible BDNF-KO } \\
\text { in forebrain: early KO }\end{array}$ & BW, FC, FST, LA, RI & $\begin{array}{l}\text { No changes in BW or aggressiviness, } \\
\text { hyperactive phenotype, impaired contextual } \\
\text { and cue memory }\end{array}$ & $\begin{array}{l}\text { Mixed background: } \\
\text { BL6/SJL } \times \text { ICR } \times I C R \times \\
\text { BI6/sv129 }\end{array}$ & Monteggia et al., 2004 \\
\hline $\begin{array}{l}\text { Inducible BDNF-KO } \\
\text { in forebrain }\end{array}$ & FST & $\begin{array}{l}\text { Antidepressant-like effect of ketamine was } \\
\text { blocked }\end{array}$ & $\begin{array}{l}\text { Mixed background: } \\
\text { BL6/SJL } \times \text { ICR } \times I C R \times \\
\text { BI6/sv129 }\end{array}$ & Autry et al., 2011 \\
\hline $\begin{array}{l}\text { Conditional } \\
\text { BDNF-KO: postnatal } \\
\text { brain }\end{array}$ & BW, FI, LA, LD & $\begin{array}{l}\text { Increased appetite, weight and anxiety-like } \\
\text { behavior, hyperactivity }\end{array}$ & Mixed background & Rios et al., 2001 \\
\hline $\begin{array}{l}\text { BDNF (Val66Met) } \\
\text { polymorphism }\end{array}$ & $\begin{array}{l}\text { EPM, FC, LA, NSF, } \\
\text { OF, RI }\end{array}$ & $\begin{array}{l}\text { Increased weight, aggressiveness, and } \\
\text { anxiety-like behavior, impaired contextual but } \\
\text { intact cue memory. No changes in locomotor } \\
\text { activity }\end{array}$ & C57BI/6J & Chen et al., 2006 \\
\hline $\begin{array}{l}\text { BDNF (Val66Met) } \\
\text { polymorphism }\end{array}$ & $\begin{array}{l}\text { Spontaneus olfactory } \\
\text { discrimination }\end{array}$ & Impairment in olfactory system & C57BI/6 & Bath et al., 2008 \\
\hline $\begin{array}{l}\text { BDNF (Val66Met) } \\
\text { polymorphism }\end{array}$ & $\begin{array}{l}\text { EPM, FST, NSF, OF, } \\
\text { SP, TM, WM }\end{array}$ & $\begin{array}{l}\text { Depression- and anxiety-like behavior, poor } \\
\text { spontaneus alteration only after stress. } \\
\text { Rescuing effect of desipramine but not } \\
\text { fluoxetine in FST }\end{array}$ & - & Yu et al., 2012 \\
\hline $\begin{array}{l}\text { BDNF } \\
\text { overexpressing, } \\
\text { hemizygous }\end{array}$ & $\begin{array}{l}\text { ASR, EPM, FC, FST, } \\
\text { LD, OF, PPI, RR, SA, } \\
\text { TM, TST }\end{array}$ & $\begin{array}{l}\text { Impaired working memory, but normal } \\
\text { contextual and cue memory, impairments in } \\
\text { ASR and PPI, anxiety-like behavior in LD but } \\
\text { not in EPM. Normal motor and locomotor } \\
\text { function, no changes in depression-like } \\
\text { behavior }\end{array}$ & C57BI/6J & Papaleo et al., 2011 \\
\hline
\end{tabular}

Abbreviations: ASR, Acustic startle response; BW, body weight; EPM, elevated plus-maze; FC, fear conditioning; Fl, food intake; FST, forced swimming test; LA, locomotor activity; LD, light-dark box; NSF, novelty suppressed feeding; OF, open field; PPI, pre-pulse inhibition; RI, resident-intruder test; RR, rotarod; SA, social approach; SP, sucrose preference; TST, tail suspension test; TM, T-maze; WM, water maze.

TetOp-Cre $\times$ floxed BDNF) mice in which BDNF expression can be knocked out upon withdrawal of doxycycline from the diet. When doxycycline was absent during early development, these mice showed a hyperactive phenotype and impairments in contextual and cued memory tasks. By contrast, when doxycycline was absent during adulthood these mice had a milder phenotype only showing some impairments in contextual memory tasks. In addition, mice with adulthood BDNF knock down do not show any baseline depression-like behaviors in behavioral despair models, however, antidepressant-like effects are lost (Monteggia et al., 2004; Autry et al., 2011). Autry et al. (2009) also examined the effects of chronic unpredictable stress (CUS) on similar mice. The authors found that female mice with induced BDNF knock down were more vulnerable to CUS-induced anxiogenic and anhedonic behaviors while male knock down mice did not differ from wildtype littermates. 
To study more localized effects of BDNF deletion, Adachi et al. (2008) injected adeno-associated virus (AAV)-driven Cre into either the DG or CA1 area of flBDNF mice to specifically delete BDNF expression in these areas. The authors found that loss of BDNF in the DG or CA1 did not affect locomotor activity, contextual memory, cued memory, or baseline anxietylike, depression-like and hedonic behaviors. However, deletion of BDNF in the DG, but not CA1, blocked the effect of ADs in a behavioral despair model. By contrast, local lentiviral knock down of BDNF in the rat dorsal DG results in anhedonic and depression-like behaviors (Taliaz et al., 2010). Signs of anhedonia were also seen when BDNF knock down was specifically targeted to the ventral subiculum, a region that has close connections with brain centers that regulate emotional behavior. However, when BDNF knock down was directed to the dorsal CA3 region of the HC, no effects were observed (Taliaz et al., 2010).

Chen et al. (2006) produced Val66Met SNP knock-in mice. Similar to human Met carriers, both hetero- (Val/Met) and homozygous (Met/Met) Met-mice showed decreased total hippocampal volume and impaired contextual memory (Chen et al., 2006). However, the cued memory and novel environment activity were similar in Met-mice and wildtype littermates. Furthermore, Met/Met mice showed increases in weight, aggressiveness, and anxiety-like behaviors. In addition, the effects of ADs in anxiety-related tasks were lost in these mice.

The Met-mice mice have also been tested in several other studies. Both Val/Met and Met/Met knock-in mice show impairments in a spontaneous olfactory discrimination test (Bath et al., 2008), while Met/Met mice show anxiety-like behavior that can be rescued by exposure to music (Li et al., 2010). In addition, $\mathrm{Val} / \mathrm{Met}$ mice show vulnerability to stress induced anxiety- and depression-like behaviors, which can be rescued by some, but not all, ADs (Yu et al., 2012). Both human and murine Met allele carriers show impaired extinction of conditioned fear responses (Soliman et al., 2010). However, similar to other transgenic mouse models of BDNF, these mice have not conclusively clarified the connection between BDNF and the pathophysiology of depression.

Taken together, the large number of studies using mice with decreased BDNF expression has not yielded any clear connections between depression and BDNF. Several of the studies found opposing behavioral effects or no effects at all. Even though $\mathrm{BDNF}^{( \pm)}$mice display a 50\% reduction in BDNF levels throughout their entire lifespan, their behavioral phenotype is mild and varies from laboratory to laboratory. These discrepancies might be due to developmental compensatory mechanisms, variations in genetic backgrounds (Jacobson and Cryan, 2007), sex differences (Dalla et al., 2010), or inter-laboratory practices (Wahlsten et al., 2003). Furthermore, conditional KOs and mice with the Val/Met mutation have similar problems as $\mathrm{BDNF}^{( \pm)}$mice. The behavioral results vary widely depending on the laboratory and the spatial location and temporal timing of the transgenes.

\section{INHIBITION OF TrKB SIGNALING}

$\mathrm{BDNF}^{( \pm)}$mice and other approaches to decrease BDNF signaling have not provided any conclusive evidence regarding the connection between BDNF and depression-like behavior. Therefore, there is growing interest in genetic models of $\operatorname{TrkB}$ signaling (Table 3). Germline TrkB KO mice have serious developmental problems and die soon after birth (Klein et al., 1993; Rohrer et al., 1999). Only a few studies with heterozygous mice have been performed. Allen et al. (2005) found disrupted circadian rhythm in TrkB het mice. However, several conditional TrkB KO mouse lines have been produced and have permitted analyses of the behavioral effects of TrkB receptor deficiency that is spatially restricted to various brain regions.

Crossing floxed TrkB KO mice with CamK-Cre mice produces mice with TrkB deficiency in the $\mathrm{HC}$ and forebrain neocortex starting at P15. These mice are viable and have normal brain morphology (Minichiello et al., 1999). They show a hyperactive phenotype with impulsivity but do not show baseline depression-like behaviors in models of behavioral despair (Zörner et al., 2003). They also do not display anxiety-like behavior. However, the antidepressant effects of ketamine were blunted in these mice (CamK-Cre; KO on P21) (Autry et al., 2011). Mice with specific TrkB deletion in adult DG neuronal progenitors (using nestin-CreERT2 mice) show decreased locomotor activity and increased anxiety-like behavior (Bergami et al., 2008). In addition, these mice do not respond to chronic $\mathrm{AD}$ treatment (Li et al., 2008).

As an alternative to decreasing $\operatorname{TrkB}$ signaling in mice through conditional deletion of TrkB receptors, Saarelainen et al. (2000) produced transgenic mice overexpressing the truncated, dominant negative form of the TrkB receptor (TrkB.T1; used as a heterozygous). When the TrkB.T1 receptor is under the control of the Thyl promoter, it is overexpressed in postnatal neurons starting during the first few postnatal weeks (Saarelainen et al., 2000). When maintained on a CD2 (BALB/c $\times \mathrm{DBA} / 2)$ background, these mice display impaired long-term spatial memory (Saarelainen et al., 2000) and do not respond to the ADs imipramine and fluoxetine in behavioral despair models (Saarelainen et al., 2003). When these mice are backcrossed to a C57BL/6J background for more than 10 generations, they showed normal contextual learning and memory and normal social behavior (Razzoli et al., 2011; Kemppainen et al., 2012). However, these mice tend to avoid social situations when stressed (Razzoli et al., 2011). Interestingly, recent findings indicate that these mice show indifference toward the surrounding environment rather than depression-like behavior (unpublished data, Lindholm et al.).

Chen et al. (2005) used another approach to inhibit TrkB signaling and produced a knock-in mouse line with a single amino acid mutation near the ATP binding site of the TrkB receptor $\left(\operatorname{TrkB}{ }^{\mathrm{F} 616 \mathrm{~A}}\right)$. This mutation does not influence the activity of the receptor, but if the pharmacologically inert kinase inhibitor 1NMPP1 is given (Bishop et al., 1999), then the activity of the TrkB receptor is inhibited. The advantage of these mice is that TrkB activity can be specifically, rapidly, and reversibly blocked without directly influencing the expression of the TrkB receptor. TrkB ${ }^{\mathrm{F} 616 \mathrm{~A}}$ mice have been successfully used in Pavlovian conditioning model and epilepsy studies (Johnson et al., 2008; Liu et al., 2013), but large-scale behavioral studies using these mice have not yet been reported. 
Table 3 | Behavioral results of transgenic TrkB mice.

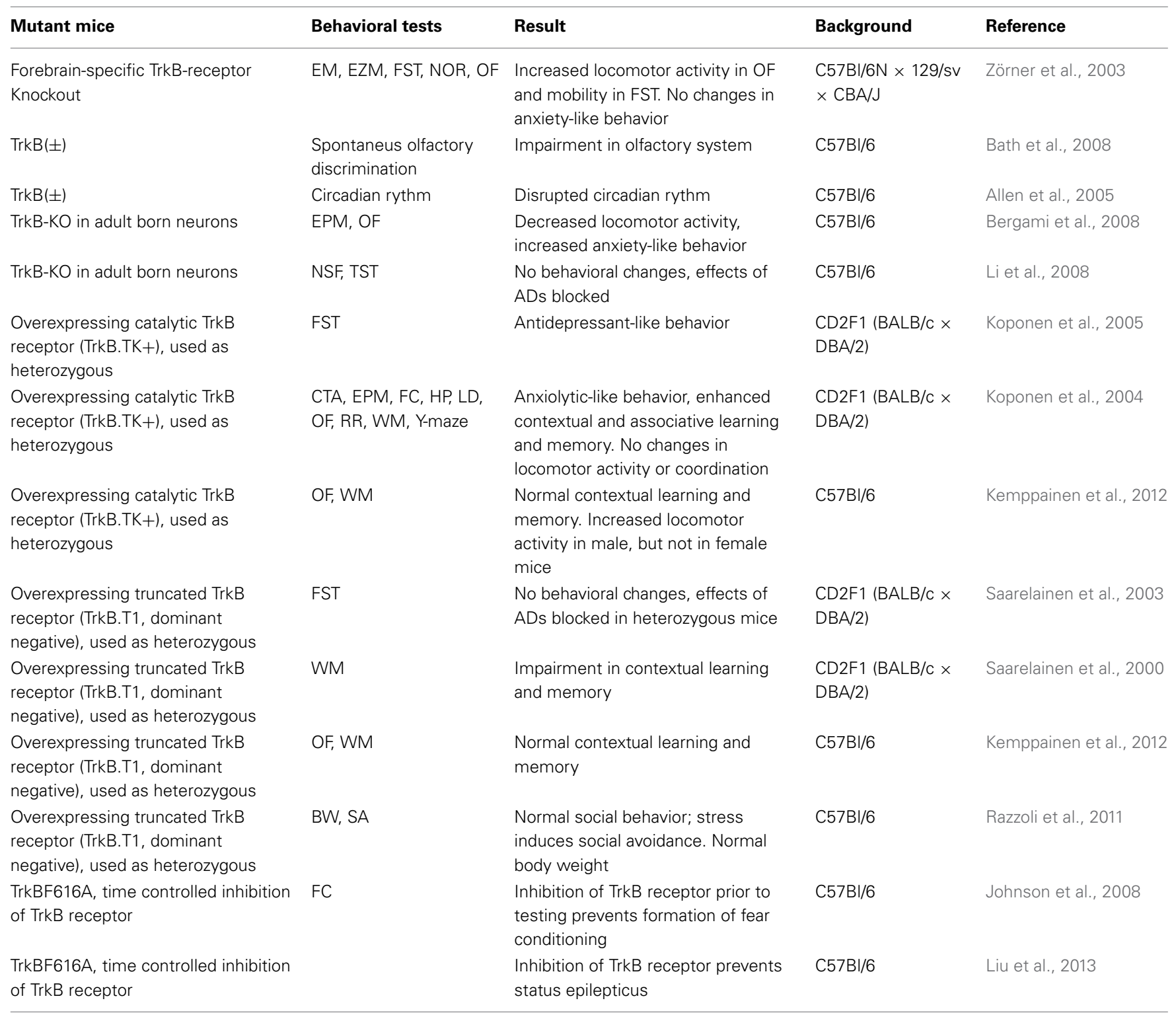

Abbreviations: BW, body weight; CTA, conditioned taste aversion; EM, emergency test; EPM, elevated plus-maze; EZM, elevated zero maze; $F C$, fear conditioning; FST, forced swimming test; HP, hotplate; LD, light-dark box; NOR, novel object recognition; NSF, novelty suppressed feeding; OF, open field; RR, rotarod; SA, social avoidance; WM, water maze.

\section{INCREASED BDNF-TrKB SIGNALING}

Direct infusion of BDNF into the DG of rat HC leads to antidepressant-like effects (Shirayama et al., 2002). This finding indicates that increasing BDNF expression in the brain could also produce an antidepressant-like behavior. One study with mice overexpressing BDNF in excitatory neurons of the forebrain (HC, cortex, and amygdala) found an antidepressantlike behavioral phenotype with increased anxiety-like behavior (Govindarajan et al., 2006). Furthermore, chronic stress did not alter the anxiety-like behavior of these mice. Another group found that the same BDNF overexpressing mice showed increased anxiety-like behavior in some but not all tests (Papaleo et al., 2011). In the same study these mice demonstrated normal motor functions, contextual and cued fear memory, social behavior, and no alterations in depression-like behaviors. However, BDNF overexpressing mice have impairments in working memory and the auditory system. The results of these two studies are in part contradictory. However, the two studies used mice of different sex, which may explain the discrepancies, because sex is known to influence behavior of genetically modified mice (Monteggia et al., 2007; Autry et al., 2009). Another line of BDNF overexpressing mice showed improved performance in learning and memory tasks (Nakajo et al., 2008).

Transgenic mice overexpressing the full-length TrkB receptor (TrkB.TK+; used as a heterozygous) under the Thyl promoter have enhanced TrkB signaling (Koponen et al., 2004). These mice 
show reduced anxiety- and depression-like behavior as well as improvements in contextual and associative learning and memory tasks without changes in locomotor activity or coordination (Koponen et al., 2004, 2005). In the forced swim test these mice behaved as if they had been treated with $\mathrm{ADs}$, and $\mathrm{AD}$ treatment failed to produce any further effects (Koponen et al., 2005). These TrkB.TK+ mice were originally bred and maintained on a CD2 $(\mathrm{BALB} / \mathrm{c} \times \mathrm{DBA} / 2)$ background but were later backcrossed to the $\mathrm{C} 57 \mathrm{BL} / 6 \mathrm{~J}$ background for more than 10 generations. However, when tested in the $\mathrm{C} 57 \mathrm{Bl} / 6 \mathrm{~J}$ background, the phenotype was much milder (Kemppainen et al., 2012). Male mice showed increased locomotor activity while female mice did not differ from controls.

\section{DISCUSSION}

The roles of neurotrophins in depression and in the mechanisms underlying antidepressant effects have been widely studied. BDNF deficient mice are the most used model for these studies. These models have demonstrated a key role for BDNFTrkB signaling in the mechanisms underlying the actions of ADs (MacQueen et al., 2001; Saarelainen et al., 2003; Chourbaji et al., 2004; Ibarguen-Vargas et al., 2009; Lindholm et al., 2012). Specifically, direct infusion of BDNF into the brain produces antidepressant-like behavior and enhances the effects of ADs, while blockade of BDNF signaling prevents the effects of ADs. It is possible that at least some of the antidepressant-like effects of BDNF are mediated through BDNF-induced long-term changes in synaptic connectivity, which in turn promote recovery from depression (Castren, 2005). The effects of acute BDNF are wellestablished in many regions of the $\mathrm{HC}$ and cortex (Messaoudi et al., 1998; Panja and Bramham, 2014), and chronic antidepressant treatment and BDNF infusion induce upregulation of an overlapping set of immediate early genes (Wibrand et al., 2006; Alme et al., 2007).

By contrast, there is no consensus as to whether decreases in BDNF activity cause depression-like behavior in mice since the results vary between different studies. The main difference between these studies is likely the temporal and spatial resolution of BDNF deficiency. However, other factors, such as developmental compensatory mechanisms, genetic backgrounds (Jacobson and Cryan, 2007), sex differences (Dalla et al., 2010), and interlaboratory practices (Wahlsten et al., 2003) may also contribute to the variable results between studies.

Another possible reason for the failure to demonstrate an association between BDNF and mood disorders is that in most mouse models BDNF or TrkB are manipulated in most or all brain areas. However, there is evidence that manipulations of BDNF or TrkB signaling in different brain areas result in differential effects (Eisch et al., 2003; Berton et al., 2006). Therefore, widespread deletions could result in opposing effects that cancel each other out. Future studies with better temporal and spatial control of BDNF and TrkB will help to clarify this issue. Finally, mice are obviously not ideal for modeling depression and anxiety disorders. Local injection of a lentivirus coding for BDNF siRNA suggests that reduction of $\mathrm{BDNF}$ levels in rat $\mathrm{HC}$ produces depression-like behavior (Taliaz et al., 2010). Therefore, it is possible that genetically altered rats might produce more consistent results than mice when attempting to assess the role of BDNF in mood disorders. However, the Val66Met polymorphism in humans has not provided any clear evidence that altered BDNF release plays a role in depression and anxiety in humans. Thus, there may not be any direct association between BDNF and mood disorders.

In summary, while the importance of BDNF and TrkB in the antidepressant response is clear, further experiments in more refined mouse and rat models and in humans are necessary to clarify the role of BDNF signaling in depression and anxiety disorders.

\section{ACKNOWLEDGMENTS}

We thank Outi Nikkilä for technical assistance and Sissi Pastell for animal care. This work was financially supported by The Academy of Finland Center of Excellence program (Eero Castrén), EU 6th Framework program (Jesse S. O. Lindholm, Eero Castrén) and the Sigrid Jusélius Foundation (Eero Castrén). Mouse behavioral unit of Neuroscience Center is supported by Biocenter Finland.

\section{REFERENCES}

Adachi, M., Barrot, M., Autry, A. E., Theobald, D., and Monteggia, L. M. (2008). Selective loss of brain-derived neurotrophic factor in the dentate gyrus attenuates antidepressant efficacy. Biol. Psychiatry 63, 642-649. doi: 10.1016/j.biopsych.2007.09.019

Allen, G. C., Qu, X., and Earnest, D. J. (2005). TrkB-deficient mice show diminished phase shifts of the circadian activity rhythm in response to light. Neurosci. Lett. 378, 150-155. doi: 10.1016/j.neulet.2004.12.023

Alme, M. N., Wibrand, K., Dagestad, G., and Bramham, C. R. (2007). Chronic fluoxetine treatment induces brain region-specific upregulation of genes associated with BDNF-induced long-term potentiation. Neural Plast. 2007:26496. doi: $10.1155 / 2007 / 26496$

Autry, A. E., Adachi, M., Cheng, P., and Monteggia, L. M. (2009). Genderspecific impact of brain-derived neurotrophic factor signaling on stress-induced depression-like behavior. Biol. Psychiatry 66, 84-90. doi: 10.1016/j.biopsych.2009.02.007

Autry, A. E., Adachi, M., Nosyreva, E., Na, E. S., Los, M. F., Cheng, P. F., et al. (2011). NMDA receptor blockade at rest triggers rapid behavioural antidepressant responses. Nature 475, 91-95. doi: 10.1038/nature10130

Bath, K. G., Mandairon, N., Jing, D., Rajagopal, R., Kapoor, R., Chen, Z. Y., et al. (2008). Variant brain-derived neurotrophic factor (Val66Met) alters adult olfactory bulb neurogenesis and spontaneous olfactory discrimination. J. Neurosci. 28, 2383-2393. doi: 10.1523/JNEUROSCI.4387-07.2008

Bergami, M., Rimondini, R., Santi, S., Blum, R., Gotz, M., and Canossa, M. (2008). Deletion of TrkB in adult progenitors alters newborn neuron integration into hippocampal circuits and increases anxiety-like behavior. Proc. Natl. Acad. Sci. U.S.A. 105, 15570-15575. doi: 10.1073/pnas.0803702105

Berton, O., McClung, C., DiLeone, R., Krishnan, V., Renthal, W., Russo, S., et al. (2006). Essential role of BDNF in the mesolimbic dopamine pathway in social defeat stress. Science 311, 864-868. doi: 10.1126/science.1120972

Bishop, A., Kung, C., Shah, K., Witucki, L., Shokat, K., and Liu, Y. (1999). Generation of monospecific nanomolar tyrosine kinase inhibitors via a chemical genetic approach. J. Am. Chem. Soc. 121, 627-631. doi: 10.1021/ja983267v

Bremner, J., Narayan, M., Anderson, E., Staib, L., Miller, H., and Charney, D. (2000). Hippocampal volume reduction in major depression. Am. J. Psychiatry $157,115-117$.

Carola, V., and Gross, C. (2010). BDNF moderates early environmental risk factors for anxiety in mouse. Genes Brain Behav. 9, 379-389. doi: 10.1111/j.1601183X.2010.00572.x

Castren, E. (2005). Opinion-is mood chemistry? Nat. Rev. Neurosci. 6, 241-246. doi: 10.1038/nrn1629

Castrén, E., Võikar, V., and Rantamäki, T. (2007). Role of neurotrophic factors in depression. Curr. Opin. Pharmacol. 7, 18-21. doi: 10.1016/j.coph.2006.08.009

Chan, J. P., Unger, T. J., Byrnes, J., and Rios, M. (2006). Examination of behavioral deficits triggered by targeting bdnf in fetal or postnatal brains of mice. Neuroscience 142, 49-58. doi: 10.1016/j.neuroscience.2006.06.002 
Chen, B., Dowlatshahi, D., MacQueen, G. M., Wang, J. F., and Young, L. T. (2001). Increased hippocampal BDNF immunoreactivity in subjects treated with antidepressant medication. Biol. Psychiatry 50, 260-265. doi: 10.1016/S00063223(01)01083-6

Chen, X., Ye, H., Kuruvilla, R., Ramanan, N., Scangos, K., Zhang, C., et al. (2005). A chemical-genetic approach to studying neurotrophin signaling. Neuron 46, 13-21. doi: 10.1016/j.neuron.2005.03.009

Chen, Z., Jing, D., Bath, K. G., Ieraci, A., Khan, T., Siao, C., et al. (2006). Genetic variant BDNF (Val66Met) polymorphism alters anxiety-related behavior. Science 314, 140-143. doi: 10.1126/science.1129663

Chourbaji, S., Hellweg, R., Brandis, D., Zorner, B., Zacher, C., Lang, U. E., et al. (2004). Mice with reduced brain-derived neurotrophic factor expression show decreased choline acetyltransferase activity, but regular brain monoamine levels and unaltered emotional behavior. Mol. Brain Res. 121, 28-36. doi: 10.1016/j.molbrainres.2003.11.002

Coppell, A. L., Pei, Q., and Zetterström, T. S. C. (2003). Bi-phasic change in BDNF gene expression following antidepressant drug treatment. Neuropharmacology 44, 903-910. doi: 10.1016/S0028-3908(03)00077-7

Dalla, C., Pitychoutis, P. M., Kokras, N., and Papadopoulou-Daifoti, Z. (2010). Sex differences in animal models of depression and antidepressant response. Basic. Clin. Pharmacol. Toxicol. 106, 226-233. doi: 10.1111/j.1742-7843.2009. 00516.x

Deltheil, T., Guiard, B. P., Cerdan, J., David, D. J., Tanaka, K. F., Repérant, C., et al. (2008). Behavioral and serotonergic consequences of decreasing or increasing hippocampus brain-derived neurotrophic factor protein levels in mice. Neuropharmacology 55, 1006-1014. doi: 10.1016/j.neuropharm.2008.08.001

Di Lieto, A., Rantamäki, T., Vesa, L., Yanpallewar, S., Antila, H., Lindholm, J., et al. (2012). The responsiveness of TrkB to BDNF and antidepressant drugs is differentially regulated during mouse development. PLOS ONE 7:e32869. doi: 10.1371/journal.pone.0032869

Duman, C. H., Schlesinger, L., Kodama, M., Russell, D. S., and Duman, R. S. (2007). A role for MAP kinase signaling in behavioral models of depression and antidepressant treatment. Biol. Psychiatry 61, 661-670. doi: 10.1016/j.biopsych.2006.05.047

Duman, C. H., Schlesinger, L., Russell, D. S., and Duman, R. S. (2008). Voluntary exercise produces antidepressant and anxiolytic behavioral effects in mice. Brain Res. 1199, 148-158. doi: 10.1016/j.brainres.2007.12.047

Duman, R. S., Heninger, G. R., and Nestler, E. J. (1997). A molecular and cellular theory of depression. Arch. Gen. Psychiatry 54, 597-606. doi: 10.1001/archpsyc.1997.01830190015002

Duman, R. S., and Monteggia, L. M. (2006). A neurotrophic model for stress-related mood disorders. Biol. Psychiatry 59, 1116-1127. doi: 10.1016/j.biopsych.2006.02.013

Dwivedi, Y., Rizavi, H. S., Conley, R. R., Roberts, R. C., Tamminga, C. A., and Pandey, G. N. (2003). Altered gene expression of brain-derived neurotrophic factor and receptor tyrosine kinase B in postmortem brain of suicide subjects. Arch. Gen. Psychiatry 60, 804-815. doi: 10.1001/archpsyc.60.8.804

Egan, M. F., Kojima, M., Callicott, J. H., Goldberg, T. E., Kolachana, B. S., Bertolino, A., et al. (2003). The BDNF val66met Polymorphism Affects Activity-Dependent Secretion of BDNF and Human Memory and Hippocampal Function. Cell 112, 257-269. doi: 10.1016/S0092-8674(03)00035-7

Eisch, A., Bolanos, C., de Wit, J., Simonak, R., Pudiak, C., Barrot, M., et al. (2003). Brain-derived neurotrophic factor in the ventral midbrain-nucleus accumbens pathway: a role in depression. Biol. Psychiatry 54, 994-1005. doi: 10.1016/j.biopsych.2003.08.003

Eisenberg, D. P., Ianni, A. M., Wei, S. M., Kohn, P. D., Kolachana, B., Apud, J., et al. (2013). Brain-derived neurotrophic factor (BDNF) Val(66)Met polymorphism differentially predicts hippocampal function in medication-free patients with schizophrenia. Mol. Psychiatry 18, 713-720. doi: 10.1038/mp.2012.187

Ernfors, P., Lee, K. F., and Jaenisch, R. (1994). Mice lacking brain-derived neurotrophic factor develop with sensory deficits. Nature 368, 147-150. doi: $10.1038 / 368147 \mathrm{a} 0$

Govindarajan, A., Rao, B. S., Nair, D., Trinh, M., Mawjee, N., Tonegawa, S., et al. (2006). Transgenic brain-derived neurotrophic factor expression causes both anxiogenic and antidepressant effects. Proc. Natl. Acad. Sci. U.S.A. 103, 13208-13213. doi: 10.1073/pnas.0605180103

Gratacos, M., Gonzalez, J. R., Mercader, J. M., de Cid, R., Urretavizcaya, M., and Estivill, X. (2007). Brain-derived neurotrophic factor Val66Met and psychiatric disorders: meta-analysis of case-control studies confirm association to substance-related disorders, eating disorders, and schizophrenia. Biol. Psychiatry 61, 911-922. doi: 10.1016/j.biopsych.2006.08.025

Gray, J., Yeo, G. S., Cox, J. J., Morton, J., Adlam, A.-L. R., Keogh, J. M., et al. (2006). Hyperphagia, severe obesity, impaired cognitive function, and hyperactivity associated with functional loss of one copy of the brain-derived neurotrophic factor (BDNF) gene. Diabetes 55, 3366-3371. doi: 10.2337/db06-0550

Gyekis, J. P., Yu, W., Dong, S., Wang, H., Qian, J., Kota, P., et al. (2013). No association of genetic variants in BDNF with major depression: a meta- and gene-based analysis. Am. J. Med. Genet. B Neuropsychiatr. Genet. 162, 61-70. doi: 10.1002/ajmg.b.32122

Hosang, G. M., Shiles, C., Tansey, K. E., McGuffin, P., and Uher, R. (2014). Interaction between stress and the BDNF Val66Met polymorphism in depression: a systematic review and meta-analysis. BMC Med. 12:7. doi: 10.1186/17417015-12-7

Huang, Y. Z., Pan, E., Xiong, Z. Q., and McNamara, J. O. (2008). Zinc-mediated transactivation of TrkB potentiates the hippocampal mossy fiber-CA3 pyramid synapse. Neuron 57, 546-558. doi: 10.1016/j.neuron.2007.11.026

Ibarguen-Vargas, Y., Surget, A., Touma, C., Palme, R., and Belzung, C. (2008). Multifaceted strain-specific effects in a mouse model of depression and of antidepressant reversal. Psychoneuroendocrinology 33, 1357-1368. doi: 10.1016/j.psyneuen.2008.07.010

Ibarguen-Vargas, Y., Surget, A., Vourc'h, P., Leman, S., Andres, C. R., Gardier, A. M., et al. (2009). Deficit in BDNF does not increase vulnerability to stress but dampens antidepressant-like effects in the unpredictable chronic mild stress. Behav. Brain Res. 202, 245-251. doi: 10.1016/j.bbr.2009.03.040

Jacobson, L. H., and Cryan, J. F. (2007). Feeling strained? Influence of genetic background on depression-related behavior in mice: a review. Behav. Genet. 37, 171-213. doi: 10.1007/s10519-006-9106-3

Johnson, A. W., Chen, X., Crombag, H. S., Zhang, C., Smith, D. R., Shokat, K. M., et al. (2008). The brain-derived neurotrophic factor receptor TrkB is critical for the acquisition but not expression of conditioned incentive value. Eur. J. Neurosci. 28, 997-1002. doi: 10.1111/j.1460-9568.2008.06383.x

Karege, F., Bondolfi, G., Gervasoni, N., Schwald, M., Aubry, J. M., and Bertschy, G. (2005). Low brain-derived neurotrophic factor (BDNF) levels in serum of depressed patients probably results from lowered platelet BDNF release unrelated to platelet reactivity. Biol. Psychiatry 57, 1068-1072. doi: 10.1016/j.biopsych.2005.01.008

Kaufman, J., Yang, B. Z., Douglas-Palumberi, H., Grasso, D., Lipschitz, D., Houshyar, S., et al. (2006). Brain-derived neurotrophic factor-5-HTTLPR gene interactions and environmental modifiers of depression in children. Biol. Psychiatry 59, 673-680. doi: 10.1016/j.biopsych.2005.10.026

Kemppainen, S., Rantamäki, T., Jeronimo-Santos, A., Lavasseur, G., Autio, H., Karpova, N., et al. (2012). Impaired TrkB receptor signaling contributes to memory impairment in APP/PS1 mice. Neurobiol. Aging 33, 1122.e23-1122.e39. doi: 10.1016/j.neurobiolaging.2011.11.006

Kernie, S. G., Liebl, D. J., and Parada, L. F. (2000). BDNF regulates eating behavior and locomotor activity in mice. EMBO J. 19, 1290-1300. doi: 10.1093/emboj/19.6.1290

Kim, Y. K., Lee, H. P., Won, S. D. Park, E. Y., Lee, H. Y., Lee, B. H., et al. (2007). Low plasma BDNF is associated with suicidal behavior in major depression. Prog. Neuropsychopharmacol. Biol. Psychiatry 31, 78-85. doi: 10.1016/j.pnpbp.2006.06.024

Klein, R., Smeyne, R. J., Wurst, W., Long, L. K., Auerbach, B. A., Joyner, A. L., et al. (1993). Targeted disruption of the trkB neurotrophin receptor gene results in nervous system lesions and neonatal death. Cell 75, 113-122. doi: 10.1016/00928674(93)90683-H

Knüsel, B., Gao, H., Okazaki, T., Yoshida, T., Mori, N., Hefti, F., et al. (1997). Ligand-induced down-regulation of Trk messenger RNA, protein and tyrosine phosphorylation in rat cortical neurons. Neuroscience 78, 851-862. doi: 10.1016/S0306-4522(96)00616-1

Koponen, E., Rantamäki, T., Voikar, V., Saarelainen, T., MacDonald, E., and Castrén, E. (2005). Enhanced BDNF signaling is associated with an antidepressant-like behavioral response and changes in brain monoamines. Cell. Mol. Neurobiol. 25, 973-980. doi: 10.1007/s10571-005-8468-z

Koponen, E., Voikar, V., Riekki, R., Saarelainen, T., Rauramaa, T., Rauvala, H., et al. (2004). Transgenic mice overexpressing the full-length neurotrophin receptor trkB exhibit increased activation of the trkB-PLC gamma pathway, reduced anxiety, and facilitated learning. Mol. Cell. Neurosci. 26, 166-181. doi: 10.1016/j.mcn.2004.01.006 
Korte, M., Carroll, P., Wolf, E., Brem, G., Thoenen, H., and Bonhoeffer, T. (1995). Hippocampal long-term potentiation is impaired in mice lacking brainderived neurotrophic factor. Proc. Nat. Acad. Sci. U.S.A. 92, 8856-8860. doi: 10.1073/pnas.92.19.8856

Kozisek, M. E., Middlemas, D., and Bylund, D. B. (2008). Brain-derived neurotrophic factor and its receptor tropomyosin-related kinase B in the mechanism of action of antidepressant therapies. Pharmacol. Ther. 117, 30-51. doi: 10.1016/j.pharmthera.2007.07.001

Lee, F. S., and Chao, M. V. (2001). Activation of Trk neurotrophin receptors in the absence of neurotrophins. Proc. Nat. Acad. Sci. U.S.A. 98, 3555-3560. doi: 10.1073/pnas.061020198

Li, W. J., Yu, H., Yang, J. M., Gao, J., Jiang, H., Feng, M., et al. (2010). Anxiolytic effect of music exposure on BDNFMet/Met transgenic mice. Brain Res. 1347, 71-79. doi: 10.1016/j.brainres.2010.05.080

Li, Y., Luikart, B. W., Birnbaum, S., Chen, J., Kwon, C. H., Kernie, S. G., et al. (2008). TrkB regulates hippocampal neurogenesis and governs sensitivity to antidepressive treatment. Neuron 59, 399-412. doi: 10.1016/j.neuron.2008.06.023

Lindholm, J. S., Autio, H., Vesa, L., Antila, H., Lindemann, L., Hoener, M. C., et al. (2012). The antidepressant-like effects of glutamatergic drugs ketamine and AMPA receptor potentiator LY 451646 are preserved in bdnf/ heterozygous null mice. Neuropharmacology 62, 391-397. doi: 10.1016/j.neuropharm.2011. 08.015

Linnarsson, S., Björklund, A., and Ernfors, P. (1997). Learning deficit in BDNF mutant mice. Eur. J. Neurosci. 9, 2581-2587. doi: 10.1111/j.14609568.1997.tb01687.x

Liu, G., Gu, B., He, X. P., Joshi, R. B., Wackerle, H. D., Rodriguiz, R. M., et al. (2013). Transient inhibition of TrkB kinase after status epilepticus prevents development of temporal lobe epilepsy. Neuron 79, 31-38. doi: 10.1016/j.neuron.2013.04.027

Liu, I. Y., Lyons, W. E., Mamounas, L. A., and Thompson, R. F. (2004). Brainderived neurotrophic factor plays a critical role in contextual fear conditioning. J. Neurosci. 24, 7958-7963. doi: 10.1523/JNEUROSCI.1948-04.2004

Lyons, W. E., Mamounas, L. A., Ricaurte, G. A., Coppola, V., Reid, S. W., Bora, S. H., et al. (1999). Brain-derived neurotrophic factor-deficient mice develop aggressiveness and hyperphagia in conjunction with brain serotonergic abnormalities. Proc. Nat. Acad. Sci. U.S.A. 96, 15239-15244. doi: 10.1073/pnas.96.26.15239

MacQueen, G. M., Ramakrishnan, K., Croll, S. D., Siuciak, J. A., Yu, G. H., Young, L. T., et al. (2001). Performance of heterozygous brain-derived neurotrophic factor knockout mice on behavioral analogues of anxiety, nociception, and depression. Behav. Neurosci. 115, 1145-1153. doi: 10.1037/0735-7044.115.5.1145

Marais, L., Stein, D. J., and Daniels, W. M. U. (2009). Exercise increases BDNF levels in the striatum and decreases depressive-like behavior in chronically stressed rats. Metab. Brain Dis. 24, 587-597. doi: 10.1007/s11011-009-9157-2

Messaoudi, E., Bardsen, K., Srebro, B., and Bramham, C. R. (1998). Acute intrahippocampal infusion of BDNF induces lasting potentiation of synaptic transmission in the rat dentate gyrus. J. Neurophysiol. 79, 496-499.

Minichiello, L., Korte, M., Wolfer, D., Kuehn, R., Unsicker, K., Cestari, V., et al. (1999). Essential role for TrkB receptors in hippocampus-mediated learning. Neuron 24, 401-414. doi: 10.1016/S0896-6273(00)80853-3

Monteggia, L. M., Barrot, M., Powell, C. M., Berton, O., Galanis, V., Gemelli, T., et al. (2004). Essential role of brain-derived neurotrophic factor in adult hippocampal function. Proc. Nat. Acad. Sci. U.S.A. 101, 10827-10832. doi: 10.1073/pnas.0402141101

Monteggia, L. M., Luikart, B., Barrot, M., Theoloold, D., Malkovska, I., Nef, S., et al. (2007). Brain-derived neurotrophic factor conditional knockouts show gender differences in depression-related behaviors. Biol. Psychiatry 61, 187-197. doi: 10.1016/j.biopsych.2006.03.021

Monteleone, P., Serritella, C., Martiadis, V., and and Maj, M. (2008). Decreased levels of serum brain-derived neurotrophic factor in both depressed and euthymic patients with unipolar depression and in euthymic patients with bipolar I and II disorders. Bipolar Disord. 10, 95-100. doi: 10.1111/j.1399-5618.2008. 00459.x

Nakajo, Y., Miyamoto, S., Nakano, Y., Xue, J. H., Hori, T., and Yanamoto, H. (2008). Genetic increase in brain-derived neurotrophic factor levels enhances learning and memory. Brain Res. 1241, 103-109. doi: 10.1016/j.brainres. 2008.08.080

Nibuya, M., Morinobu, S., and Duman, R. S. (1995). Regulation of BDNF and trkB mRNA in rat brain by chronic electroconvulsive seizure and antidepressant drug treatments. J. Neurosci. 15, 7539-7547.
Niitsu, T., Fabbri, C., Bentini, F., and Serretti, A. (2013). Pharmacogenetics in major depression: a comprehensive meta-analysis. Prog. Neuropsychopharmacol. Biol. Psychiatry 45C, 183-194. doi: 10.1016/j.pnpbp.2013.05.011

Panja, D., and Bramham, C. R. (2014). BDNF mechanisms in late LTP formation: a synthesis and breakdown. Neuropharmacology 76(Pt C), 664-676. doi: 10.1016/j.neuropharm.2013.06.024

Papaleo, F., Silverman, J. L., Aney, J., Tian, Q., Barkan, C. L., Chadman, K. K., et al. (2011). Working memory deficits, increased anxiety-like traits, and seizure susceptibility in BDNF overexpressing mice. Learn. Mem.18, 534-544. doi: $10.1101 / \mathrm{lm} .2213711$

Park, H., and Poo, M. M. (2013). Neurotrophin regulation of neural circuit development and function. Nat. Rev. Neurosci. 14, 7-23. doi: 10.1038/nrn3379

Psotta, L., Lessmann, V., and Endres, T. (2013). Impaired fear extinction learning in adult heterozygous BDNF knock-out mice. Neurobiol. Learn. Mem. 103C, 34-38. doi: 10.1016/j.nlm.2013.03.003

Rantamäki, T., Hendolin, P., Kankaanpää, A., Mijatovic, J., Piepponen, P., Domenici, E., et al. (2007). Pharmacologically diverse antidepressants rapidly activate brain-derived neurotrophic factor receptor TrkB and induce phospholipase-cgamma signaling pathways in mouse brain. Neuropsychopharmacology 32, 2152-2162. doi: 10.1038/sj.npp.1301345

Rantamäki, T., Vesa, L., Antila, H., Di Lieto, A., Tammela, P., Schmitt, A., et al. (2011). Antidepressant drugs transactivate $\operatorname{TrkB}$ neurotrophin receptors in the adult rodent brain independently of BDNF and monoamine transporter blockade. PLoS ONE 6:e20567. doi: 10.1371/journal.pone.0020567

Razzoli, M., Domenici, E., Carboni, L., Rantamäki, T., Lindholm, J., Castrén, E., et al. (2011). A role for BDNF/TrkB signaling in behavioral and physiological consequences of social defeat stress. Genes Brain Behav. 10, 424-433. doi: 10.1111/j.1601-183X.2011.00681.x

Rios, M., Fan, G., Fekete, C., Kelly, J., Bates, B., Kuehn, R., et al. (2001). Conditional deletion of brain-derived neurotrophic factor in the postnatal brain leads to obesity and hyperactivity. Mol. Endocrinol. 15, 1748-1757. doi: 10.1210/mend.15.10.0706

Rohrer, B., Korenbrot, J. I., LaVail, M. M., Reichardt, L. F., and Xu, B. (1999). Role of neurotrophin receptor TrkB in the maturation of rod photoreceptors and establishment of synaptic transmission to the inner retina. J. Neurosci. 19, 8919-8930.

Russo-Neustadt, A., Beard, R., and Cotman, C. (1999). Exercise, antidepressant medications, and enhanced brain derived neurotrophic factor expression. Neuropsychopharmacology 21, 679-682. doi: 10.1016/S0893-133X(99)00059-7

Saarelainen, T., Hendolin, P., Lucas, G., Koponen, E., Sairanen, M., MacDonald, E., et al. (2003). Activation of the TrkB neurotrophin receptor is induced by antidepressant drugs and is required for antidepressant-induced behavioral effects. J. Neurosci. 23, 349-357.

Saarelainen, T., Pussinen, R., Koponen, E., Alhonen, L., Wong, G., Sirviö, J., et al. (2000). Transgenic mice overexpressing truncated trkB neurotrophin receptors in neurons have impaired long-term spatial memory but normal hippocampal LTP. Synapse 38, 102-104. doi: 10.1002/1098-2396(200010)38:1\%3C102::AIDSYN11\%3E3.0.CO;2-K

Schmidt, H. D., and Duman, R. S. (2010). Peripheral BDNF produces antidepressant-like effects in cellular and behavioral models. Neuropsychopharmacology 35, 2378-2391. doi: 10.1038/npp.2010.114

Sen, S., Duman, R., and Sanacora, G. (2008). Serum brain-derived neurotrophic factor, depression, and antidepressant medications: meta-analyses and implications. Biol. Psychiatry 64, 527-532. doi: 10.1016/j.biopsych.2008.05.005

Sheline, Y., Wang, P., Gado, M., Csernansky, J., and Vannier, M. (1996). Hippocampal atrophy in recurrent major depression. Proc. Nat. Acad. Sci. U.S.A. 93, 3908-3913. doi: 10.1073/pnas.93.9.3908

Shirayama, Y., Chen, A. C., Nakagawa, S., Russell, D. S., and Duman, R. S. (2002) Brain-derived neurotrophic factor produces antidepressant effects in behavioral models of depression. J. Neurosci. 22, 3251-3261.

Siuciak, J. A., Lewis, D. R., Wiegand, S. J., and Lindsay, R. M. (1997). Antidepressant-like effect of brain-derived neurotrophic factor (BDNF). Pharmacol. Biochem. Behav. 56, 131-137. doi: 10.1016/S0091-3057(96)00169-4

Soliman, F., Glatt, C. E., Bath, K. G., Levita, L., Jones, R. M., Pattwell, S. S., et al. J. (2010). A genetic variant BDNF polymorphism alters extinction learning in both mouse and human. Science 327, 863-866. doi: 10.1126/science. 1181886

Taliaz, D., Stall, N., Dar, D. E., and Zangen, A. (2010). Knockdown of brain-derived neurotrophic factor in specific brain sites precipitates behaviors associated 
with depression and reduces neurogenesis. Mol. Psychiatry 15, 80-92. doi: $10.1038 / \mathrm{mp} .2009 .67$

Uutela, M., Lindholm, J., Louhivuori, V., Wei, H., Louhivuori, L. M., Pertovaara, A., et al. (2012). Reduction of BDNF expression in Fmrl knockout mice worsens cognitive deficits but improves hyperactivity and sensorimotor deficits. Genes Brain Behav. 11, 513-523. doi: 10.1111/j.1601-183X.2012.00784.x

Verhagen, M., van der Meij, A., van Deurzen, P. A., Janzing, J. G., Arias-Vasquez, A., Buitelaar, J. K., et al. (2008). Meta-analysis of the BDNF Val66Met polymorphism in major depressive disorder: effects of gender and ethnicity. Mol. Psychiatry 15, 260-271. doi: 10.1038/mp.2008.109

Wahlsten, D., Metten, P., Phillips, T., Boehm, S., Burkhart-Kasch, S., Dorow, J., et al. (2003). Different data from different labs: lessons from studies of geneenvironment interaction. J. Neurobiol. 54, 283-311. doi: 10.1002/neu.10173

Wibrand, K., Messaoudi, E., Havik, B., Steenslid, V., Lovlie, R., Steen, V. M., et al. (2006). Identification of genes co-upregulated with arc during BDNF-induced long-term potentiation in adult rat dentate gyrus in vivo. Eur. J. Neurosci. 23, 1501-1511. doi: 10.1111/j.1460-9568.2006.04687.x

Yeo, G. S., Connie Hung, C. C., Rochford, J., Keogh, J., Gray, J., Sivaramakrishnan, S., et al. (2004). A de novo mutation affecting human TrkB associated with severe obesity and developmental delay. Nat. Neurosci. 7, 1187-1189. doi: $10.1038 / \mathrm{nn} 1336$

Yu, H., Wang, D. D., Wang, Y., Liu, T., Lee, F. S., and Chen, Z. Y. (2012). Variant brain-derived neurotrophic factor Val66Met polymorphism alters vulnerability to stress and response to antidepressants. J. Neurosci. 32, 4092-4101. doi: 10.1523/JNEUROSCI.5048-11.2012
Zetterström, T., Pei, Q., and Grahame-Smith, D. (1998). Repeated electroconvulsive shock extends the duration of enhanced gene expression for BDNF in rat brain compared with a single administration. Mol. Brain Res. 57, 106-110. doi: 10.1016/S0169-328X(98)00077-1

Zörner, B., Wolfer, D. P., Brandis, D., Kretz, O., Zacher, C., Madani, R., et al. (2003). Forebrain-specific trkB-receptor knockout mice: behaviorally more hyperactive than "depressive." Biol. Psychiatry 54, 972-982. doi: 10.1016/S00063223(03)00418-9

Conflict of Interest Statement: The authors declare that the research was conducted in the absence of any commercial or financial relationships that could be construed as a potential conflict of interest.

Received: 26 February 2014; accepted: 10 April 2014; published online: 30 April 2014. Citation: Lindholm JSO and Castrén E (2014) Mice with altered BDNF signaling as models for mood disorders and antidepressant effects. Front. Behav. Neurosci. 8:143. doi: 10.3389/fnbeh.2014.00143

This article was submitted to the journal Frontiers in Behavioral Neuroscience.

Copyright (c) 2014 Lindholm and Castrén. This is an open-access article distributed under the terms of the Creative Commons Attribution License (CC BY). The use, distribution or reproduction in other forums is permitted, provided the original author(s) or licensor are credited and that the original publication in this journal is cited, in accordance with accepted academic practice. No use, distribution or reproduction is permitted which does not comply with these terms. 